\section{Forest Bibliography}

Two parts of the "Forest Bibliography to 1933" have now been issued from the Department of Forestry of the University of Oxford. This work has been compiled by Prof. R. S. Troup and his staff. The systematic referencing of current forest literature was commenced at Oxford in 1920, and continued jointly by the Forestry Department and the Imperial Forestry Institute after 1924. The object at first was to provide staff and students with facilities for keeping in touch with forestry literature. Recently, in response to requests, publication was decided upon. The Bibliography comprises literature published to the end of 1933, and contained in the library of the Oxford Department of Forestry. Forest literature published on and after January 1, 1934, is being dealt with under the decimal system of classification prepared by Dr. Flury and recently adopted by the International Union of Forest Research Organizations. The Oxford Bibliography is said to comprise a fairly complete list of material published in English and a considerable amount of literature published in French and German. Material from other countries is mainly confined to literature where an English, French or German summary is appended. The first part opens with a list of abbreviated titles and then gives the subjects of classification as $A$, General Forestry ; $B$, Sylviculture; $C$, Forest Protection; $D$, Forest Utilization; $E$, Forest Mensuration; $F$, Forest Valuation and Finance; $G$, Forest Management ; $H$, Forest Policy and Economics ; I, Meteorology ; $J$, Geology ; $K$, Education and Research ; $L$, Terminology and Classification of Information; $M$, Engineering and Surveying; $N$, Botany; $O$, Invertebrate Zoology; $P$, Biography. Most of these branches are divided into sub-heads.

\section{The Strangeways Research Laboratory}

THE investigations described in the report of the Strangeways Research Laboratory, Cambridge, for 1936 fall into two main divisions : one is concerned with the growth and development of cells and tissues, or with their organization in the embryo; the other deals with the action of radiations on the living cell, with the object of analysing their destructive effect so that the different forms can be used to the best advantage in the treatment of cancer. The methods of cell culture have found many applications in the work of biological and medical laboratories. The Strangeways Laboratory continues to attract workers from other centres, who go to Cambridge to obtain instruction and practice in a difficult and still relatively unfamiliar technique. The Trustees point out that the income of the laboratory is chiefly made up of grants from public bodies and corporations and donations from individuals, which cannot be regarded as permanent. The great need is an endowment to provide an income not necessarily large but assured, so that plans may be laid for the future in reasonable security. Additional space is required for the visitors to the laboratory and for the development of the work on experimental embryology, which has now reached a stage when expert assistance from biochemists is urgently needed. The Trustees express the hope that a capital sum sufficient to provide an extension to the present building may be forthcoming, as well as sufficient funds to provide the requisite additional annual income.

\section{Training in Business Administration}

EstABLISHed seven years ago, the Department of Business Administration at the London School of Economics provides a post-graduate course extending normally over one year for men and women who intend to follow a business career. It has been found that such post-graduate students are of three main types. First, there are university graduates in economics, commerce or Modern Greats who require chiefly to learn the practical application of principles of which they are already familiar. Secondly, there are graduates in modern languages and technical subjects such as chemistry and engineering who already have technical qualifications which would often enable them to obtain immediate employment without difficulty. Later on, however, as they rise to positions of responsibility, they may find themselves obliged to exercise functions of management for which their technical training by itself provides little preparation. Training in business management should enable them to avoid many of the initial mistakes inevitable in a process of learning by trial and error. Thirdly, there are students who have already had considerable experience of business and who come or are sent by their employers to widen their outlook and increase their capabilities. At first sight it would seem difficult, if not impossible, to frame a course which would be equally suitable for these different groups, with their varying types of training and background. Experience has shown, however, that given appropriate methods of teaching, the lack of homogeneity in the class is a source of strength rather than of weakness. The work is carried on mainly in a series of discussion classes, to which each student can contribute from his own special knowledge.

\section{Memorial to the late Viscount Grey of Fallodon}

THE report of the Natural History Society of Northumberland, Durham, and Newcastle-uponTyne, presented at the annual meeting on October 26, states that the North Country Memorial takes the form of a simple inscription engraved upon the masonry of the Hancock Museum in Newcastle, near the entrance. An essential part of the memorial was the creation of an endowment fund which would help to ensure the continuance of the Museum itself, and this Memorial Endowment Fund now amounts to $£ 6,156$. The sum is none too large for its purpose, but the fund is still open, and it is hoped that further donations will be received. The summary of accounts which is included in the report shows that the payments for the past year exceeded the receipts by $£ 52$ 19s. 10d. The Museum itself is a valuable educational institution, and while the number of ordinary visitors is slightly down at 12,348 , the increasing use made of the exhibits by classes of pupils from Newcastle Council Schools is encouraging. During the year, 1,337 scholars visited the Museum with their teachers, and arrangements have been 
made whereby pupils of the schools under the Northumberland County Education Committee may share in the advantages hitherto restricted to town children.

\section{Garden Plants from China}

AN interesting account of the botanical pioneers who first made known the wonderful flora of China, appears in the Journal of the Royal Horticultural Society (62, Pt. 8, 347-351, August 1937). It is mainly a review of a "History of European Botanical Discoveries in China" by E. Bretschneider. The volume is one of the treasures of the Society's Lindley Library, and the article is from the pen of Mr. F. C. Stern. It was not until nearly 400 years after Marco Polo's celebrated journey that Europeans took an interest in the decorative plants of China. Domenicus Parenin first mentioned Wistaria chinensis in 1698, but Father Pierre d'Incarville was probably the first botanical collector in China, about half a century later. It was not until the early part of last century, however, that Chinese plants began to find their way into European gardens; previous collections had been for herbarium material. The work of Dr. Abel, John Reeves, Robert Fortune, Dr. Hance, Father Armand David, Father Jean Marie Delavay, Nicolai Przewalski, Dr. Augustine Henry and other investigators of last century, is described. The account of their collections makes interesting reading, and the plants they introduced are among the greatest contributors to garden beauty.

\section{Tokyo Earthquakes of 1936}

THE last Seismometric Report issued by the Earthquake Research Institute completes the list of earthquakes felt in Tokyo in 1936. In addition to the central station, there are eleven others at various distances up to eighty-four miles from Tokyo, and the records obtained at these stations have enabled the position of the epicentre in all the earthquakes, and the focal depth in all but three, to be determined. The year 1936 is notable on two accounts. It is the year of fewest earthquakes in the district since the network of stations was formed, the number being only 31 , or less than half the average number (64) in the preceding twelve years. Also, more than half the centres were submarine, 14 lying beneath the Pacific Ocean, 4 below Tokyo Bay, and only 13 under land. The depth of focus ranges from $15 \mathrm{~km}$. to 80 $\mathrm{km}$., the average being $45 \mathrm{~km}$. None of the earthquakes was of destructive strength, but in one-that of November 3-the shock was of degree 7 of the Rossi-Forel scale or strong enough to throw down ornaments, vases, etc. Indeed, only four of the 797 earthquakes in the thirteen years were strong enough to cause slight damage to buildings.

\section{The Rubber Research Institute, Malaya}

THE year 1937 will stand out in the history of the Rubber Research Institute, Malaya, as it marks the beginning of a second decade of activity and was the occasion of the occupation of new premises. The purpose and recent work of the Institute are well described in an illustrated booklet and the annual report for 1936, both of which have recently been published (Kuala Lumpur : The Institute). Research work is carried out in four main divisions, botanical, pathological, chemical and soils respectively. Many of the investigations are necessarily made in the field, both at the Institute's Experimental Station and also on, and in co-operation with, a large number of estates throughout Malaya. Retrenchment of staff during the slump and a disastrous fire in 1936 seriously curtailed the activities of the Institute, but a period of expansion is now coming into being, and the rapid development of the advisory work is good evidence that this service is appreciated by estate owners and small-holders alike.

\section{Deep Well Drilling}

AT the Rumanian Branch of the Institution of Petroleum Technologists, on November 27, a discussion was held on problems of deep well drilling. (J. Inst. Pet. Tech., 23; 1937). Mr. G. Elias opened by summarizing the points he considered most influential in successful drilling to depth. Accidents must be avoided at all costs, and the only way to safeguard against them is by provision of suitable equipment, drillers and crews. Mud conditions must be good, as they are invariably reflected in the condition of the well itself. The ultimate cost of the well and drilling time are largely dependent on the selection of a suitable casing programme, and this should be drawn up in new areas immediately the necessary information is available from first wells. An adequate steam supply should be available on the site, not only to reduce the time factor, but also to ensure that a big volume of mud is circulated. Particular care should be taken to see that adequate derricks are employed and also that their foundations are such as to prohibit uneven settling.

\section{Maternal Mortality}

THe Ministry of Health has issued two reports upon this subject, namely, (a) "An Investigation into Maternal Mortality in England", and (b) "Maternal Mortality in Wales" (London : H.M. Stationery Office. 5s. $6 d$., and 2s. 6d., respectively). The national average for maternal mortality has remained for a number of years in the neighbourhood of 4 mothers per 1,000 live births, despite great expansions in maternity services and remarkable improvement in the general health of the community. The provisional figures for 1936 show a slight decline, the rate for that year being less than 4. In many districts in England and in Wales, however, the maternal mortality rate is higher than the average, being 5 or more, and the two reports survey the circumstances that may be responsible for this excessive mortality in England and Wales, and the measures that may be taken to reduce it. The rate is generally higher in industrial areas and lower in rural ones. The first report deals more fully with prevention, and a section is devoted to the subject of abortion. Attempted abortions appear to be frequent and on the increase, as well as to be responsible for a number of deaths from puerperal sepsis. 